\title{
Assessment of chlorophyll- $a$ and sea surface temperature variability around the Mascarene Plateau, Nazareth Bank (Mauritius) using satellite data
}

\author{
V. RAMCHANDUR ${ }^{1}$, SOONIL D. D. V. RUGHOOPUTH ${ }^{2}$, R. BHOOJAWON ${ }^{2}$ \\ AND B. A. MOTAH ${ }^{1}$ \\ ${ }^{1}$ Mauritius Oceanography Institute, Albion, Mauritius \\ ${ }^{2}$ University of Mauritius, Reduit, Mauritius \\ e-mail:vramchandur@moi.intnet.mu
}

\begin{abstract}
The Mascarene Plateau is characterised by shallow banks namely Saya de Malha and Nazareth which are known to harbour high phytoplankton biomass along the slope down to the ridge. Correlation between sea surface temperature (SST) and Chlorophyll- $a$ (Chl- $a$ ) distribution surrounding the plateau was investigated. Higher Chl- $a$ concentration was observed during the period July to September, indicating higher productivity due to upwelling. The regions east $\left(61-63^{\circ} \mathrm{E}\right)$ and west $\left(57-59^{\circ} \mathrm{E}\right)$ of the Mascarene Plateau were also studied along latitudes $13^{\circ} \mathrm{S}$ up to $18^{\circ} \mathrm{S}$ in the exclusive economic zone of Mauritius, where most of the fishing activities are concentrated. In general, 2008 was observed to be less warm during the past 14 years registering a drop with respect to the maximum monthly mean records, whilst 2006 was the most productive during winter season in the region of study. Chl- $a$ bloom was observed after cyclone Imelda in April 2013 showing Chl- $a$ concentration above $0.3 \mathrm{mg} \mathrm{m}^{-3}$ along latitude $13^{\circ} \mathrm{S}$ and longitude $57^{\circ} \mathrm{E}$. The study reveals that the western side of the plateau is more productive with relatively warmer surface temperature compared to the eastern side of the plateau.
\end{abstract}

Keywords: Chlorophyll- $a$, Phytoplankton, Sea surface temperature, Upwelling

\section{Introduction}

The Indian Ocean is different compared to other world oceans because of its near-complete enclosure with the continents and the year-round current patterns (Schott and McCreary, 2001). The Mascarene Plateau arches across the Western Indian Ocean from the Seychelles down to Mauritius. The plateau has a unique topography with islands and shallow banks (Parson and Evans, 2005) and sustains an extensive range of ecosystems with great potential for exploitation of resources (Payet, 2005). The Mascarene Plateau lies along the westward flow of the south equatorial current (SEC), primarily driven by the strong south-east trade winds originating from between $10^{\circ} \mathrm{S}$ and $30^{\circ} \mathrm{S}$ (Schott and McCreary, 2001). There is constant current over the shallow banks in the central region of the plateau all year round (New et al., 2007; Pous et al., 2010; Miller et al., 2015). This eventually creates an upwelling effect with a rise in primary production (Sarma et al., 2010), leading to a higher phytoplankton biomass along both sides of the slope down to the ridge (Gallienne et al., 2004).

Ocean colour remote sensing can be used to estimate Chl- $a$ which in turn is used to monitor phytoplankton and productivity of oceans (Platt et al., 2008). These techniques are cost-effective and provide a wide range of observations for monitoring changes in aquatic systems (Chen et al., 2005, 2006; Andrefouet et al., 2008). There is a significant difference in the spatial and temporal distribution from deep ocean to coastal areas and from region to region based on the environmental conditions (Rinaldi et al., 2014). Factors affecting Chl- $a$ distribution are mainly physical processes such as wind driven upwelling, river discharge, shelf morphology, sea surface current pattern and other environmental parameters. Alternatively, SST cooling is a proxy for surface water nutrient enrichment in the process of vertical transport from deeper colder layers in coastal upwelling systems (Bignami et al., 2008, Silio-Calzada et al., 2008). The south-west Indian Ocean upwelling at around $55-80^{\circ} \mathrm{E}$; $4-12^{\circ} \mathrm{S}$ triggers climate variation (Schott et al., 2002; $\mathrm{Xie}$ and Zhu, 2008) and as a result satellite images show relatively high Chl- $a$ concentration.

The results of Chl- $a$ and SST data from the oceans can be useful for fishery information. Tunas have been observed to aggregate in areas showing temperature variations (Carruthers et al., 2014). In general, locating fish movement is not an easy task, nevertheless the fish behaviour can be related to oceanographic parameters such as SST (fronts), Chl- $a$ (containing nutrients) and ocean currents (Iglesias et al., 2007; Chassot et al., 2011; 
Sholva et al., 2013). Remote sensing techniques can play a vital role for fisheries management by identifying areas with high chlorophyll and sea surface temperature variations (Klemas, 2013). Sea-WiFS and MODISAqua Ocean colour sensor are the main sources of ocean productivity data for assessing the ocean state. Sea-WiFS has been in service since September 1997 (continuously until December 2010) and Moderate Resolution Imaging Spectroradiometer (MODIS) since July 2002. As mentioned earlier, the use of remote sensing data has been immensely exploited for the monitoring of large zones in the oceans, hence helping users to analyse more information than isolated points at a lower cost (Picado et al., 2014).

\section{Materials and methods}

Study area

The study focused on the Mascarene Plateau, situated in north Mauritius (Fig. 1) within the exclusive economic zone (EEZ). This region is mostly exploited by fishing vessels licensed by the Government of Mauritius. The area is very unique based on the morphology of the plateau and the current dynamics. The principle bank in the region of study is Nazareth Bank which is typically 20-100 m deep.

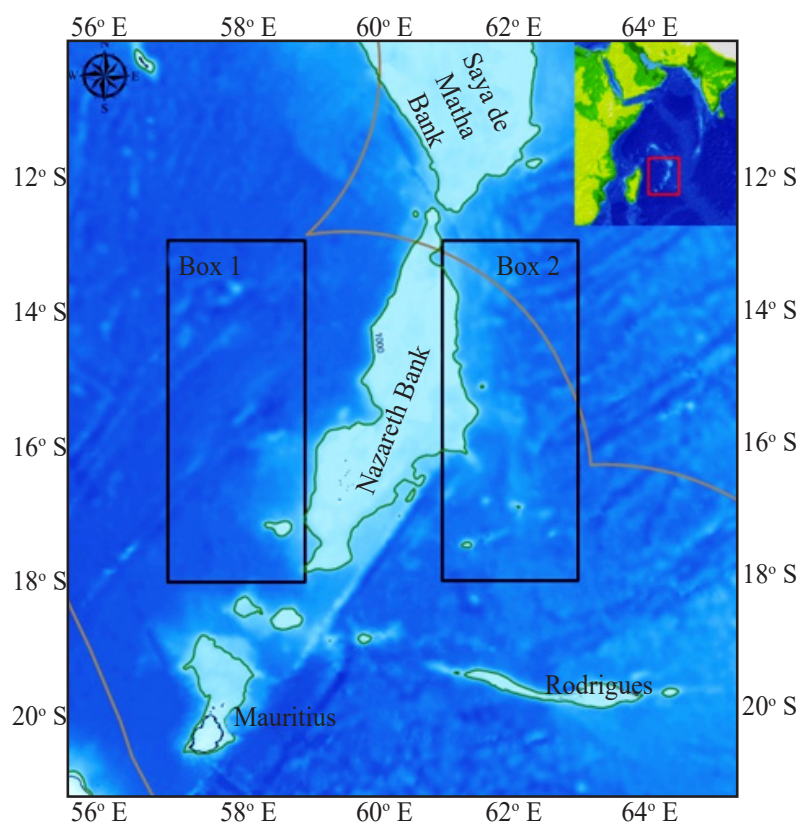

Fig. 1. Nazareth and Saya de Malha banks on the Mascarene Plateau along with Box 1 (with upper left coordinate $13^{\circ} \mathrm{S}, 57^{\circ} \mathrm{E}$ and lower right $18^{\circ} \mathrm{S}, 59^{\circ} \mathrm{E}$ ) and Box 2 (with upper left coordinate $13^{\circ} \mathrm{S}, 61^{\circ} \mathrm{E}$ and lower right $18^{\circ} \mathrm{S}, 63^{\circ} \mathrm{E}$ ) being the region of interest for analysis on both sides of the plateau

\section{Remote sensing images}

Datasets of Chl- $a$ and SST analysed in this work cover the period from January 2003 to December 2015. At first, Chl- $a$ and SST seasonal distribution were analysed to characterise the variability over the EEZ. Four seasons were considered for the analysis: north-east monsoon from December to March (DJFM), south-west monsoon from July to September (JAS) and two inter-monsoons from April to June (AMJ) and October to November (ON).

\section{MODIS Aqua Chl-a}

Satellite level 3 Standard Mapped Imagery of Chl- $a$ data were extracted from MODIS through NASA's Goddard Space Centre (http://oceancolor.gfsc.nasa.gov) for the period of study with a spatial resolution of $4 \mathrm{~km}$. Based on the long-term assessment, monthly composite was averaged for the study period compiling a set of 156 images. The seasonal analysis was computed from the monthly composite. Studies by Devassy and Goes (1991) show that the surface Chl- $a$ concentration varied between 0.005 and $0.15 \mathrm{mg} \mathrm{m}^{-3}$ on an average in the EEZ region of Mauritius. Due to the rather low Chl- $a$ concentration in open seas, two regions, adjacent to the Plateau (Box 1, 2 in Fig. 1) were chosen based on fish catch criteria. Monthly averages were preferred to daily or 8 day composite for maximum coverage of the region as previous studies used monthly products for long-term trend analysis (Behrenfeld et al., 2006, Brewin et al., 2012, Tilstone et al., 2013). In the EEZ of Mauritius, the Chl- $a$ concentration reveals large differences between coastal regions and the open seas. Normally, Chl- $a$ concentration is higher than $1 \mathrm{mg} \mathrm{m}^{-3}$ around coastal waters as a factor of nutrients coming through coastal run-off and upwelling and does not exceed $1 \mathrm{mg} \mathrm{m}^{-3}$ in high seas surface water (Tew-Kai and Marsac, 2009).

\section{MODIS Aqua sea surface temperature}

SST data used are from MODIS level 3 Standard Mapped Image of $4 \mathrm{~km}$ resolution, which in turn was obtained from the Ocean Colour website. Data were successively averaged with the same temporal resolutions as for Chl- $a$ data. The seasonal analysis for the four seasons together with monthly climatology was performed for the period of 2003-2015, where the time series data were extracted in NetCDF format processed in Matlab. The monthly average was calculated using the following equation:

$$
\mathrm{P}_{\text {average }}=\frac{\sum_{\mathrm{i}=1}^{\mathrm{n}} \mathrm{Pi}}{\mathrm{n}-\mathrm{k}}
$$

where, $\mathrm{k}=$ Number of no value pixels, $\mathrm{n}=$ Sum of total number of pixels, $\mathrm{P}_{\text {average }}=$ Calculated average of pixels over the defined period $n$. 
Time series analysis based on cluster analysis

A spatial total tuna catch data of 2011 and 2012 was computed to identify regions which are most and least exploited. For each $1^{0} \times 1^{0}$ latitude/longitude block calculated, it gives the total amount of catch in blocks for the region. Based on these facts, a time series analysis was performed using Chl- $a$ and SST monthly images in regions with high level of catch. Similarly, the analysis was done in regions with low catches, in order to differentiate the physical and biological parameters prevailing in the region. SST against Chl- $a$ graph shows the variation between these two parameters in the long term analysis together with the mean, maximum and minimum values.

\section{Hovmoller plot}

The impact of upwelling signature on the blooms is described through Hovmoller plots which were plotted using monthly average data for the period 2003-2015. The time series analysis technique compares and correlates the Hovmoller plots of the two variables being studied. Using these two techniques, areas of anomalies and main features were clearly observed. It is important to note that the Hovmoller plot along the longitude reveals minor differences in the open seas over a short range of latitude while the differences are noticeable when analysis is done along the latitude over a short range of longitude.

\section{Results and discussion}

\section{Chl-a seasonal patterns}

The effect of the SEC can be clearly observed over the four seasons bringing nutrients all the way from East Indian Ocean (Schott and McCreary, 2001) showing less significant Chl- $a$ concentration especially in DJFM season (Fig. 2) with values below $0.01 \mathrm{mg} \mathrm{m}^{-3}$. The months of April to June show the lowest concentration in the EEZ of Mauritius.

The highest Chl- $a$ concentration occurs between July and November in the northern latitudes $\left(12^{\circ} \mathrm{S}\right.$ towards the equator) with values between 0.01 to $0.3 \mathrm{mg} \mathrm{m}^{-3}$. Regions closer to the Mascarene Plateau exhibit slightly higher Chl- $a$ concentration similar to northern latitudes during JAS and ON, compared to the other seasons. This increase is observed due to the northward shift and increase in chlorophyll distribution as described by Hermes and Reason (2008), increasing the water column mixing that favours upwelling and eventually increasing surface nutrients. It shows the regions are more productive during the SW monsoon, which is in contrast with the fishing activities that show more concentration in summer season.

\section{Monthly climatology}

The daily SST and Chl- $a$ were temporally averaged to produce their respective monthly climatology for
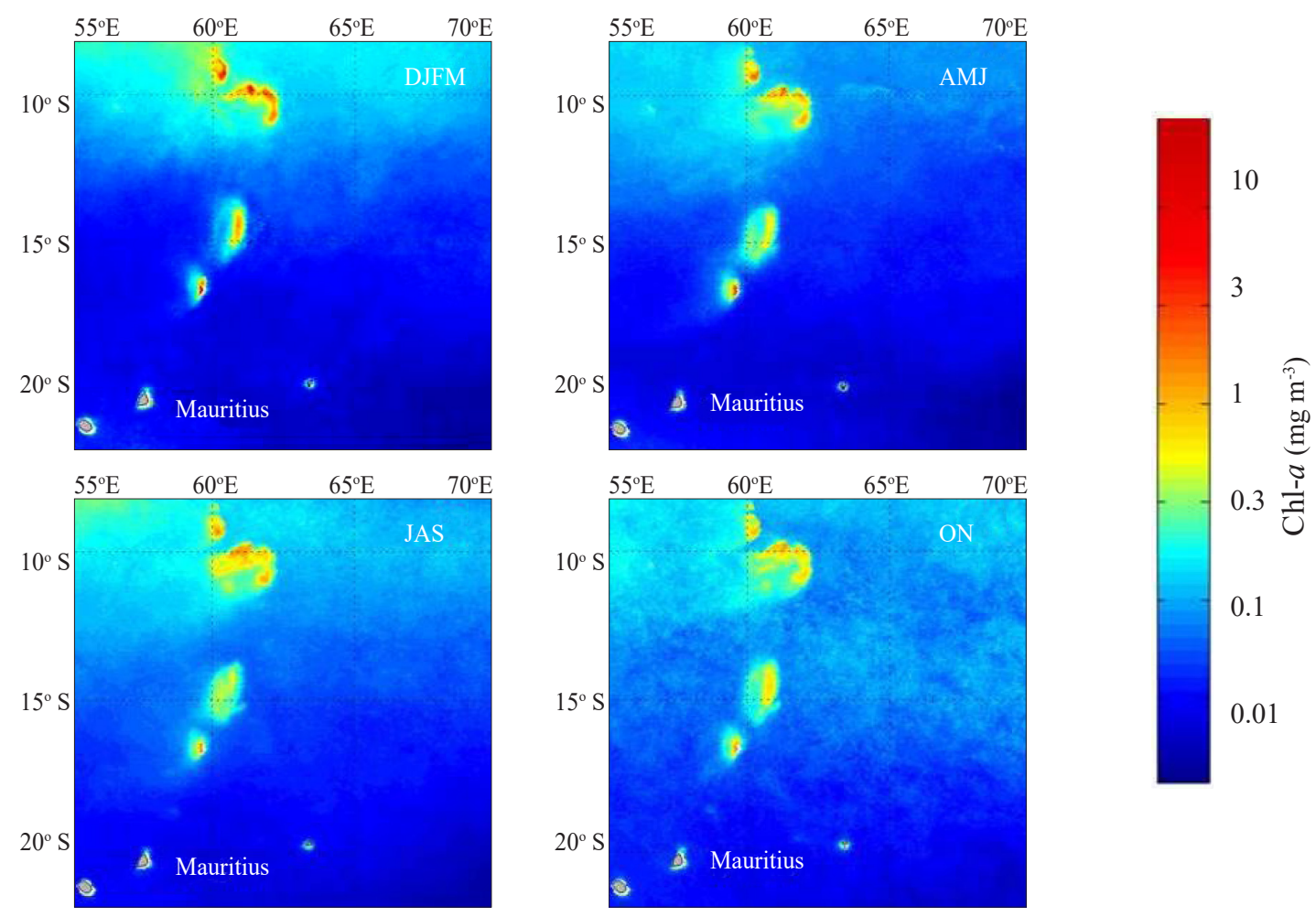

Fig. 2. Seasonal Chl- $a$ distribution ( $\mathrm{mg} \mathrm{m}^{-3}$ ) for DJFM, AMJ, JAS and ON during 2003 to 2015 
the region. The SST shows a sinusoidal seasonal cycle, with persistent seasonal warming trend from end winter (October) to summer (March). There is a clear temperature shift from the southern ocean to the equator from the two different seasons. The change in the region of study is clearly visible from the monthly climatology analysis, with a peak in February and trough in August.

This analysis is vital for identifying migrating fish species, since they migrate within a range of typical temperature along a region (Nieto et al., 2015). The monthly cycle of SST at a larger span of time is chosen to observe the trend of temperature along the latitudes. The climatological cycle of Chl- $a$ (Fig. 2) shows larger spatial change along the Mascarene Plateau compared to the SST, which is mostly due to the nutrient coming up along the deep basin around the plateau as highlighted by New et al. (2005).

\section{Seasonal patterns of sea surface temperature}

The monthly seasonal values were labelled in temperature contours that are in nearly horizontal contour lines due to year round current, which show the water distribution dynamics in the seasons (Fig. 3). The northwestern area in DJFM shows the hottest season while the latitude of southern Madagascar in JAS indicates the coldest season. SST around Mascarene Plateau shows a constant change throughout the seasons with temperature range of $26-30^{\circ} \mathrm{C}$ in $\mathrm{DJFM}, 25-27^{\circ} \mathrm{C}$ in $\mathrm{AMJ}, 24-26^{\circ} \mathrm{C}$ in JAS and $25-27^{\circ} \mathrm{C}$ in $\mathrm{ON}$. This range of temperature is further discussed in the time series analysis computed in different regions. Effect of the SEC is clearly observed along the seasons with the temperature contours diverting as they reach the coast of Madagascar showing similar SST along the eastern coast in JAS. The reason why the Seychelles regions are productive is due to the high level of Chl- $a$ concentration seen in the four seasons and also the low temperature variations between the four seasons under study.

\section{Time series analysis}

Time series for seasonal mean of Chl- $a$ and SST for the study period highlights the seasonal and spatial variability of both parameters on the sides of the plateau along latitudes 13 to $18^{\circ} \mathrm{S}$. The time series plots indicate mean monthly values of Chl- $a$ and SST along with the minimum and maximum values that occurred during the study period in blocks of $1^{0} \times 1^{0}$. For comparison, year 2015 was plotted on the same axis to indicate the variation on a temporal scale. Generally, Chl- $a$ decreases in summer season, attaining its lowest concentration between January/February whereas the highest peak occurs during the month of July. There is a clear overview of the high increase in biological production (Chl- $a$ ) in winter season as a result of high nutrient levels converging
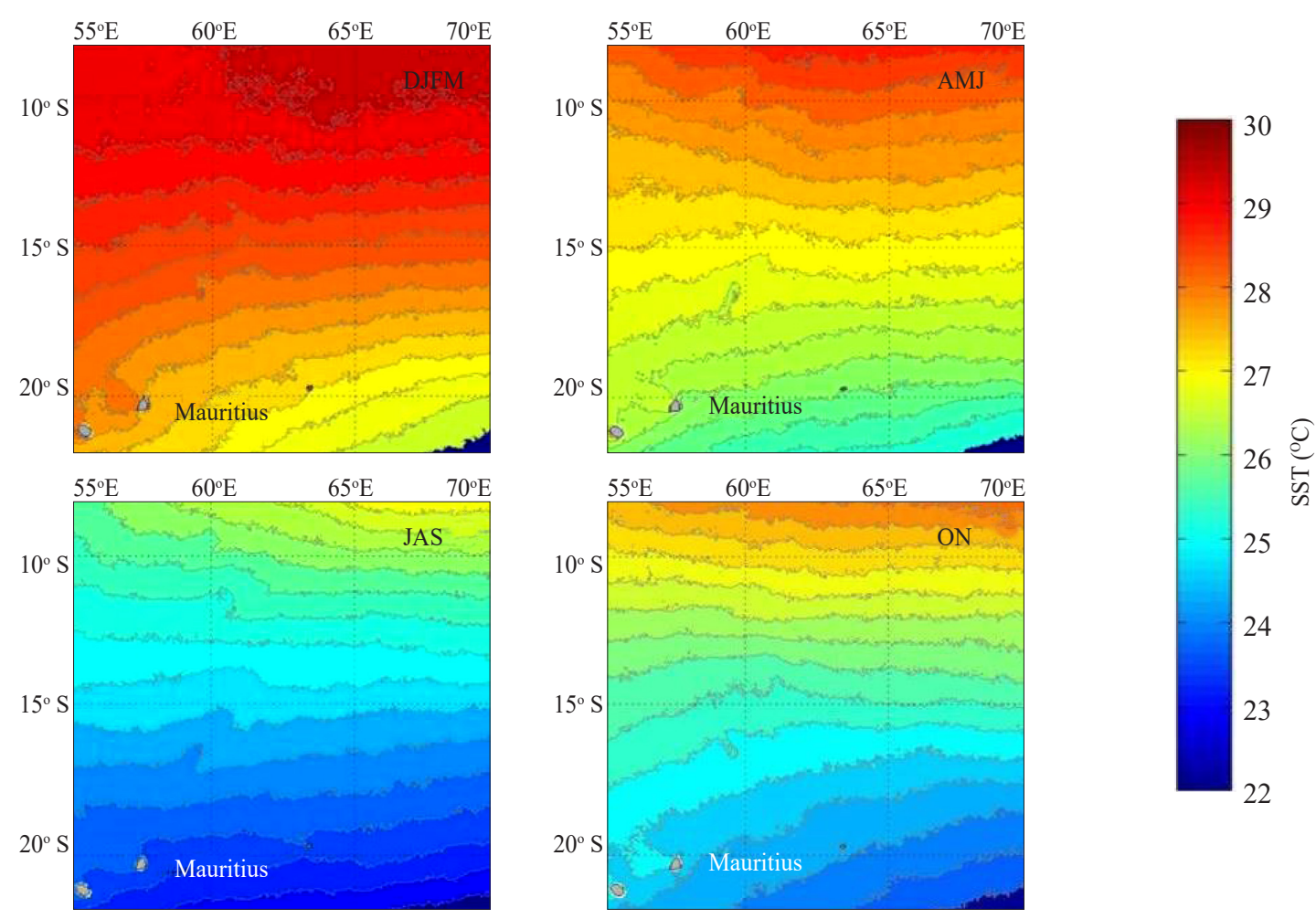

Fig. 3. Seasonal SST for DJFM, AMJ, JAS and ON during 2003 to 2015 with the line highlighting temperature contours 
to the surface waters (New et al., 2005). The west side of the plateau shows relatively high concentrations $\left(0.15-0.2 \mathrm{mg} \mathrm{m}^{-3}\right)$ between approximately 13 to $15^{0} \mathrm{~S}$. Surface temperature shows a sinusoidal cycle with persistent seasonal warming trend from January to March. Approximately $1^{\circ} \mathrm{C}$ decrease can be observed based on the monthly climatological long term analysis data between latitude 13 and $18^{\circ} \mathrm{S}$. The lowest surface temperature occurs in August which approximately correlates with the high Chl- $a$ concentration. The Chl- $a$ values range from $0.1-0.15 \mathrm{mg} \mathrm{m}^{-3}$ on both sides of plateau, and the same conditions were observed in 2015. The eastern side of the plateau $\left(57^{\circ} \mathrm{E}\right)$ shows a high temperature recorded in March 2015 (Fig. 4a) compared to the long term analysis whereas the temperature was almost the same from January to March 2015 for lower latitude (Fig. 4c). At higher latitudes $\left(13^{\circ} \mathrm{S}\right)$ two peaks can be observed for SST (2015) in January and March on the eastern part of the plateau (Fig. 4b), in contrast with lower latitudes $\left(17^{0} \mathrm{~S}\right)$ where the highest temperature occurred in February (Fig. 4d).

\section{Hovmoller plot}

Hovmoller plots generated from time series of SST and Chl- $a$ for the study area $\left(57\right.$ to $\left.59^{\circ} \mathrm{E}\right)$ and $\left(61\right.$ to $\left.63^{\circ} \mathrm{E}\right)$ between latitudes 10 and $18^{\circ} \mathrm{S}$ are shown in Fig. $5 \mathrm{a}$ and $\mathrm{b}$.
The annual cycle of SST showed a clear seasonal pattern with minimum value from April to September with the range expanding more towards latitude $18^{\circ} \mathrm{S}$ rather than towards the equator. A peak surface temperature gradient was also identified in February and every two years extrapolating along the longitudes being analysed in the western part of the plateau. High Chl- $a$ concentration in winter was noticed in the region, from May to September with peak in July along the longitudes. Surface temperature analyses show that the year 2008 was less warm, with a sudden rise in SST in 2009. Also it can be observed that the last seven years were warmer in summer and years 2014 and 2015 were less cold in winter. High Chl- $a$ concentration was noticed from May to August annually which is the result of mixing of cold water with nutrients coming from southern latitudes; but there was a decrease in 2009, 2010 and 2011 compared to other years. Year 2006 was more productive compared to other years showing relatively high Chl- $a$ concentration (above $0.01 \mathrm{mg} \mathrm{m}^{-3}$ ) along the temporal scale.

Analysis based on the seasonal pattern shows the effect of the south equatorial current (SEC) on Chl- $a$ concentration as observed by Jury et al. (2010) which indicates a shift from Western Indian Ocean towards the East African coast. Between July and September, the level of Chl- $a$ concentration is higher. The input of surface

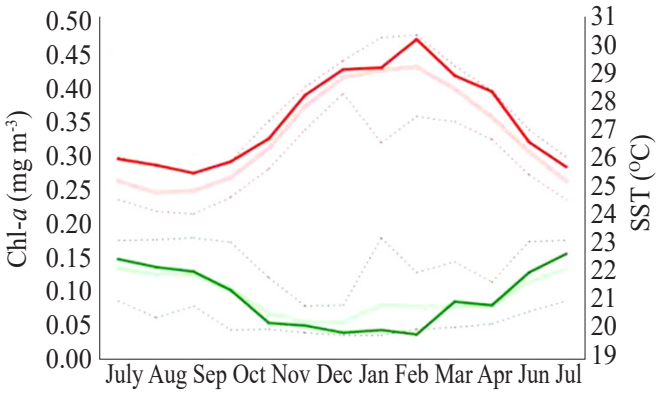

(a)

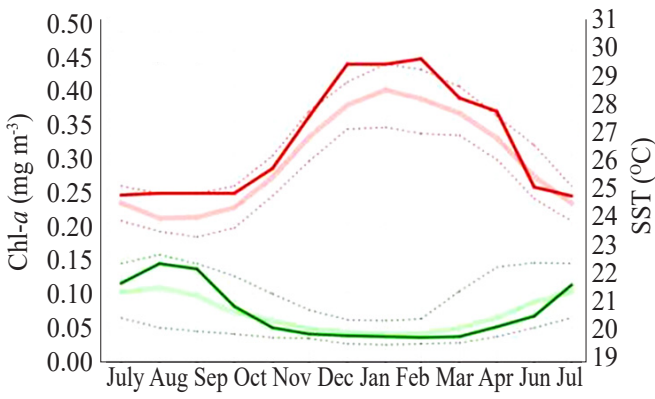

(c)

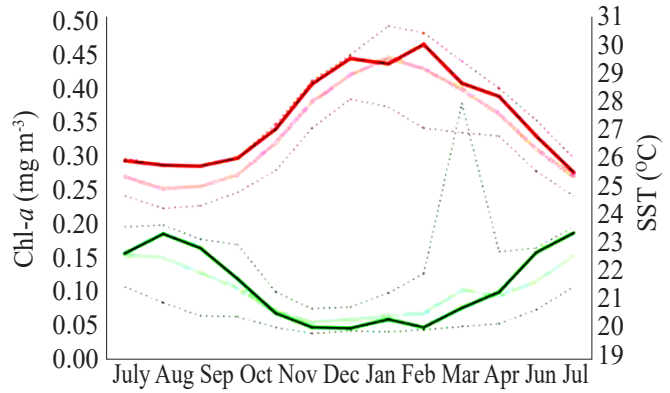

(b)

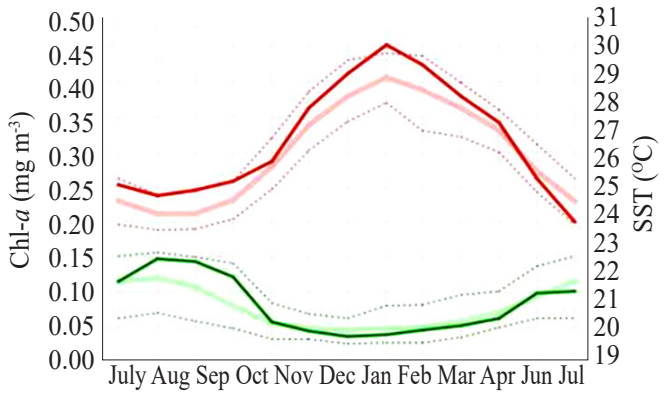

(d)

$$
\begin{array}{llll}
\text { - Chl- } a \text { TS } & \cdots & \text { Chl- } a \text { LTA Min. - Chl- } a \text { LTA Mean … Chl- } a \text { LTA Max. } \\
\text { - SST TS } & \cdots & \text { SST LTA Min. } & \text { - SST LTA Mean }
\end{array}
$$

Fig. 4. Time series analysis in four different regions. (a): $57^{\circ} \mathrm{E} 13^{\circ} \mathrm{S}$; (b): $61^{\circ} \mathrm{E} 13^{\circ} \mathrm{S}$; (c): $57^{\circ} \mathrm{E} 17^{\circ} \mathrm{S} ;(\mathrm{d}): 61^{\circ} \mathrm{E} ; 17^{\circ} \mathrm{S}$, along $57^{\circ} \mathrm{E}$ and $61^{\circ} \mathrm{E}$, showing Chl- $a$ and SST long term analysis (mean, minimum and maximum values and data for 2015) 

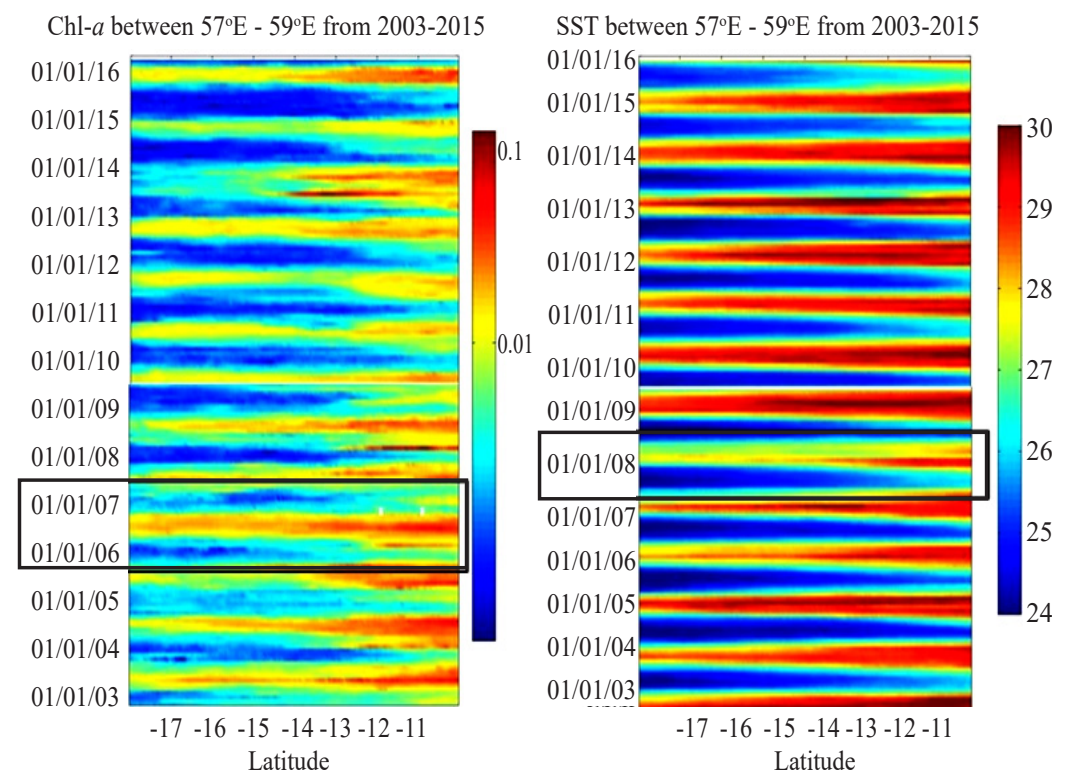

Fig. 5a. Hovmoller plot of Chl- $a$ (left) and SST (right) along longitude $57^{\circ} \mathrm{E}-59^{\circ} \mathrm{E}$
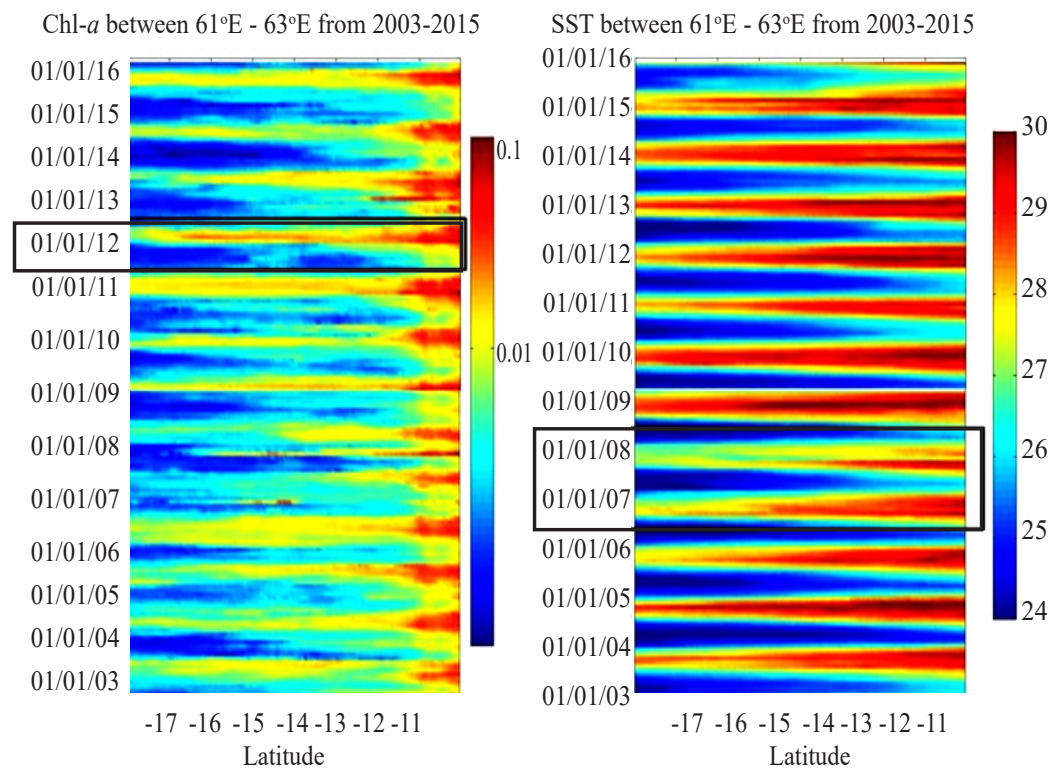

Fig. 5b. Hovmoller plot of Chl- $a$ (left) and SST (right) along longitude $61^{\circ} \mathrm{E}-63^{\circ} \mathrm{E}$

cold water starts from AMJ to JAS across the southern latitudes (below $10^{\circ} \mathrm{S}$ ) and the effect is relatively low above the SEC. DJFM represents the hottest months with surface temperature ranging from 25 to $27^{\circ} \mathrm{C}$ around the Mascarene Plateau. The shallow banks around the plateau exhibits relatively high Chl- $a$ concentration mostly as a result of the shallow bathymetry (approximately $100 \mathrm{~m}$ ) and also as a factor of the steep slope. In general, between the latitudes $25^{\circ} \mathrm{S}$ and $30^{\circ} \mathrm{S}$, there is a high mixing of Chl- $a$ concentration in February.

The lowest Chl- $a$ concentration occurs between January and February whereas July can be described as the month with highest concentration. The difference in surface temperature between latitudes $10^{\circ} \mathrm{S}$ and $18^{\circ} \mathrm{S}$ is approximately $1^{\circ} \mathrm{C}$ throughout the year, which could be a good indicator for fish niche. Results from the time series plots and grid analysis show similar patterns and the after effect of cyclone Imelda can be clearly depicted by Chl- $a$ bloom in April 2013 in the region $\left(57^{\circ} \mathrm{E}, 13^{\circ} \mathrm{S}\right)$ with recorded values above $0.3 \mathrm{mg} \mathrm{m}^{-3}$. Small changes in surface temperature show a high rate of Chl- $a$ change in the western side of the plateau. Based on analysis from scatter plot, a high coefficient of determination $\left(\mathrm{R}^{2}\right)$ of 0.6142 was observed on the west side of the plateau 
compared to the lowest coefficient $(0.2715)$ east of the plateau, resulting in slow rate of change between Chl- $a$ and SST. Based on observations from the Hovmoller plot, year 2008 was less warm from actual observations with a drop of approximately $2^{\circ} \mathrm{C}$ compared to the maximum temperature recorded from monthly mean. It can therefore be concluded that Chl- $a$ concentration is higher along the latitude $11^{\circ} \mathrm{S}$ southward on the west of the plateau $\left(57^{\circ} \mathrm{E}-59^{\circ} \mathrm{E}\right)$, implying higher productive zone with relatively high surface temperature with regard to the other side of the plateau.

This study based on SST and Chl- $a$ derived from satellite imagery in the Mascarene Plateau could be used together with fishing information (Lan et al., 2012) so as to determine seasonal fish aggregation.

\section{Acknowledgements}

The authors acknowledge all those who have contributed to this paper. The satellite data were provided by NASA Goddard Space Flight Center, Ocean Ecology Laboratory, Ocean Biology Processing Group and data under the MESA programme. The authors appreciate the financial support from the University of Mauritius. They also thank Antoine Royer from the JRC and Kwame Adu Agyekum for their useful comments on the manuscript and for the help in programming.

\section{References}

Andrefouet, S., Costello, M. J., Rast, M. and Sathyendranath, S. 2008. Earth observations for marine and coastal biodiversity and ecosystems. Rem. Sens. Environ., 112: 3297-3299.

Behrenfeld, M. J., O’Malley, R. T., Siegel, D. A., McClain, C. R., Sarmiento, J. L., Feldman, G. C., Milligan, A. J., Falkowski, P. G., Letelier, R. M. and Boss, E. S. 2006. Climate-driven trends in contemporary ocean productivity. Nature, 444(7120): $752-755$.

Bignami, F., Bohm, E., D’Acunzo, E., D’Archino, R. and Salusti, E. 2008. On the dynamics of surface cold filaments in the Mediterranean Sea. J. Mar. Systems, 74: 429-442.

Brewin, R. J. W., Hirata, T., Hardman-Mountford, N. J., Lavender, S. J., Sathyendranath, S. and Barlow, R. 2012. The influence of the Indian Ocean Dipole on interannual variations in phytoplankton size structure as revealed by Earth observation. Deep sea research, Part II: Topical studies in oceanography, 77-80: 117-127.

Carruthers, T., Fonteneau, A. and Hallier, J. P. 2014. Estimating tag reporting rates for tropical tuna fleets of the Indian Ocean. Fish. Res., 155: 20-32.

Chassot, E., Bonhommeau, S., Reygondeau, G., Nieto, K., Polovina, J. J., Huret, M., KDulvy, N. and Demarcq, H. 2011. Satellite remote sensing for an ecosystem approach to fisheries management. ICES J. Mar. Sci., 68: 651-666.
Chen, I. C., Lee, P. F. and Tzeng, W. N. 2005. Distribution of albacore (Thunnus alalunga) in the Indian Ocean and its relation to environmental factors. Fish. Oceanogr., 14(1): 71-80.

Chen, Q., Zhang, Y. and Hallikainen, M. 2006. Water quality monitoring using remote sensing in support of the EU water framework directive (WFD): A case study in the Gulf of Finland. Environ. Monit. Assess., 124: 157-166.

Devassy, V. P. and Goes, J. I. 1991. Phytoplankton assemblages and pigments in the exclusive economic zone of Mauritius (Indian Ocean). Indian J. Mar. Sci., 20: 163-168.

Gallienne, C. P., Conway, D. V. P., Robinson, J., Naya, N., William, J. S., Lynch, T. and Meunier, S. 2004. Epipelagic mesozooplankton distribution and abundance over the Mascarene Plateau and Basin, south-western Indian Ocean. J. Mar. Biol. Ass. U. K., 84(4321): 1-8.

Hermes, J. C. and Reason, C. J. C. 2008. Annual cycle of the South Indian Ocean (Seychelles-Chagos) thermocline ridge in a regional ocean model. J. Geophys. Res., 113: C04035.

Iglesias, A., Dafonte, C., Arcay, B. and Cotos, J. M. 2007. Integration of remote sensing techniques and connectionist models for decision support in fishing catches. Environ. Model. Softw., 22(6): 862-870.

Jury, M., McClanahan, T. and Maina, J. 2010. West Indian Ocean variability and East African fish catch. Mar. Environ. Res., 70(2): 162-170.

Klemas, V. 2013. Fisheries applications of remote sensing: An overview. Fish. Res., 148: 124-136.

Lan, K. W., Kawamura, H., Lee, M. A., Lu, H. J., Shimada, T., Hosoda, K. and Sakaida, F. 2012. Relationship between albacore (Thunnus alalunga) fishing grounds in the Indian Ocean and the thermal environment revealed by cloud-free microwave sea surface temperature. Fish. Res., 113(1): 1-7.

Miller, M. J., Feunteun, E., Aoyama, J., Watanabe, S., Kuroki, M., Lecomte-Finiger, R., Minegishi, Y., Robinet, T., Reveillac, E., Gagnaire, P. A., Berrebi, P., Tsukamoto, K. and Otake, T. 2015. Biodiversity and distribution of leptocephali west of the Mascarene Plateau in the southwestern Indian Ocean. Progress Oceanogr., 137(Part A): 84-102.

New, A., Stansfield, K., Smythe-Wright, D., Smeed, D., Evans, A. and Alderson, S. 2005. Physical and biochemical aspects of the flow across the Mascarene Plateau in the Indian Ocean. Phil. Trans. Royal Soc. London A., 363: 151-168.

New, A. L., Alderson, S. G., Smeed, D. A. and Stansfield, K. L. 2007. On the circulation of water masses across the Mascarene Plateau in the South Indian Ocean. Deep sea research Part I: Oceanographic research papers, 54: 42-74.

Nieto, K., Xu, Y., Teo, S. L. H., McClatchie, S. and Holmes, J. 2015. How important are coastal fronts to albacore tuna (Thunnus alalunga) habitat in the Northeast Pacific Ocean? Progress Oceanogr., DOI:10.1016/j.pocean.2015.05.004 
Parson, L. M. and Evans, A. J. 2005. Seafloor topography and tectonic elements of the Western Indian Ocean. Phil. Trans. R. Soc. A., 363: 15-24.

Payet, R. 2005. Research, assessment and management on the Mascarene Plateau: a large marine ecosystem perspective. Phil. Trans. R. Soc. A., 363(1826): 295-307.

Picado, A., Alvarez, I., Vaz, N., Varela, R., Gomez-Gesteira, M. and Dias, J. M. 2014. Assessment of chlorophyll variability along the northwestern coast of Iberian Peninsula. J. Sea Res., 93: 2-11.

Platt, T., Hoepffner, N., Stuart, V. and Brown, C. 2008. Why Ocean Colour? The Societal Benefits of Ocean Colour Technology, IOCCG Report No. 7.

Pous, S., Feunteun, E. and Ellien, C. 2010. Investigation of tropical eel spawning area in the South-western Indian Ocean: Influence of the oceanic circulation. Progress Oceanogr., 86: 396-413.

Rinaldi, E., Buongiorno Nardelli, B., Volpe, G. and Santoleri, R. 2014. Chlorophyll distribution and variability in the Sicily Channel (Mediterranean Sea) as seen by remote sensing data. Continental Shelf Res., 77: 61-68.

Sarma, Y. V. B., Krishna, V. V. G., Rao, D. P. and Sastry, J. S. 2010. Thermohaline circulation and water characteristics around Mauritius group of islands. Indian J. Mar. Sci., 19: 196-200.
Schott, F. A., Dengler, M. and Schoenefeldt, R. 2002. The shallow overturning circulation of the Indian Ocean. Progress Oceanogr., 53: 57-103.

Schott, F. A. and McCreary, J. P. 2001. The monsoon circulation of the Indian Ocean. Progress Oceanogr., 51: 1-123.

Sholva, Y., Sitohang, B. and Wikantika, K. 2013. New approach to locate upwelling and thermal-front from satellite imagery data. Procedia Technol., 11: 317-326.

Silio-Calzada, A., Bricaud, A. and Gentili, B. 2008. Estimates of sea surface nitrate concentrations from sea surface temperature and chlorophyll concentration in upwelling areas: A case study for the Benguela system. Rem. Sens. Environ., 112: 3173-3180.

Tew-Kai, E. and Marsac, F. 2009. Patterns of variability of sea surface chlorophyll in the Mozambique Channel: A quantitative approach. J. Mar. Systems, 77: 77-88.

Tilstone, G. H., Lotliker, A. A., Miller, P. I., Ashraf, P. M., Kumar, T. S., Suresh, T., Ragavan, B. R. and Menon, H. B. 2013. Assessment of MODIS-Aqua chlorophyll-a algorithms in coastal and shelf waters of the eastern Arabian Sea. Continental Shelf Res., 65: 14-26.

Xie, J. and Zhu, J. 2008. Estimation of the surface and mid-depth currents from Argo floats in the Pacific and error analysis. J. Mar. Systems, 73(1-2): 61-75. 